\title{
KEBIJAKAN PEMERINTAH KABUPATEN PONOROGO DALAM PELESTARIAN SITUS PENINGGALAN SEJARAH TAHUN 2000-2015
}

\author{
Hemy Kiswinarso \& Muhammad Hanif*
}

\begin{abstract}
Abstrak
Penelitian ini bertujuan untuk mengetahui kebijakan Pemerintah Kabupaten Ponorogo Dalam Pelestarian Situs Peninggalan Sejarah. Lokasi penelitian ini di wilayah Kabupaten Ponorogo dan di khususkan di wilayah yang terdapat situs peninggalan sejarah.

Penelitian ini menggunakan pendekatan kualitatif dengan jenis penelitian deskriptif. sumber data yang digunakan dalam penelitian ini adalah sumber data primer dan sekunder. Pengumpulan data menggunakan observasi, wawancara dan dokumentasi. Validasi yang digunakan dalam untuk menguji kebenaran data menggunakan triangulasi sumber penelitian, sedangkan analisis data menggunakan analisis data model interaktif.

Hasil penelitian yang diperoleh adalah sebagai berikut : kebijakan pemerintah Kabupaten Ponorogo dalam pelestarian situs peninggalan sejarah mengacu pada Undang-Undang Republik Indonesia No. 11 Tahun 2010 Tentang Cagar Budaya. Dinas Kebudayaan Pariwisata Pemuda dan Olahraga adalah Badan Dinas yang berperan langsung dalam penanganan pelestarian situs peninggalan sejarah. Dalam mengupayakan pelestarian situs peninggalan sejarah Pemerintah Kabupaten Ponorogo bekerja sangat lamban karena masih adanya kasus-kasus yang mengancam keberadaan warisan budaya tersebut. Sementara baru 2 sampai 3 tahun ini ada keseriusan dari pemerintah. Pemerintah Kabupaten Ponorogo mengupayakan adanya pendataan yang terstruktur, karena sebelumnya belum ada pembukuan untuk keterangan kebendaan cagar budaya. Pengadaan Balai Penyelamatan Benda Cagar Budaya oleh Pemerintah kota sudah diupayakan. Upaya pemerintah tersebut merupakan salah satu langkah untuk menjaga, memberdayakan, dan pemanfaatan yang lebih maksimal. Sehingga diharapkan kebijakan pemerintah dapat mengoptimalkan perlindungan situs peninggalan sejarah agar mampu dimanfaatkan oleh masyarakat umum khususnya masyarakat Kapubaten Ponorogo.
\end{abstract}

\section{Kata Kunci : Kebijakan Pemerintah, Pelestarian, Situs Peninggalan Sejarah}

\section{Pendahuluan}

Indonesia merupakan salah satu negara kepulauan yang memiliki potensi budaya dan sumber daya yang melimpah. Disamping itu pula Indonesia merupakan salah satu negara di dunia yang memiliki latar belakang sejarah yang panjang (Soebijantoro, 2013: 52). Keragaman budaya yang beragam di Indonesia ini terbentuk dari adanya proses kebiasaan manusia pada masa lampau. Proses manusia pada masa lampau ini menciptakan suatau hal yang menghasilkan berbagai warisan budaya yang beragam jenisnya. Salah satunya adalah benda atau situs bersejarah. Benda atau situs sejarah merupakan warisan budaya yang diciptakan oleh adanya proses kegiatan manusia pada masa lampau. Situs Cagar Budaya adalah lokasi yang berada di darat dan atau di air yang mengandung benda cagar budaya, bangunan cagar budaya, dan atau struktur cagar budaya sebagai hasil kegiatan manusia atau bukti kejadian masa lampau (Undang-Undang Republik Indonesia Nomor. 11 Pasal 1 Ayat 5 Tahun 2010).

Soebijantoro (2013: 55) berpendapat bahwa terdapat banyak istilah yang sering digunakan oleh masyarakat untuk menyebutkanya, mulai dari benda kuno, 
barang antik, hingga peninggalan arkeologi (archeological remains). Benda bersejarah atau benda cagar budaya merupakan benda yang perlu dilindungi dan dilestarikan. Karena benda peninggalan bersejarah adalah bukti kebenaran dari suatu peradaban nenek moyang kita pada masa lampau yang nyata akan keberadaanya. Benda cagar budaya memiliki sifat yang unik, langka, serta tidak dapat diperbaharui dan tidak bisa digantikan oleh teknologi dan bahan yang sama serta yang sangat penting adalah kesemuanya merupakan fakta aktifitas manusia pada masa lampau (Soebijantoro, 2013: 55).

Terlepas dari hal itu, pada kenyataanya keberadaan akan benda-benda bersejarah di Indonesia mulai terancam keberadaanya. Banyak kasus yang beredar pada saat ini mencengangkan para pemerhati sejarah. Mulai dari perawatan yang tidak sesuai dengan prosedur, kehilangan, bahkan pencurian yang dilakukan oleh pihak yang tidak berwenang yang menjual salah satu aset negara ini kesembarang orang, bahkan ke luar negeri. Bukan hal yang aneh apabila kita sering mendengar adanya kasus salah kelola, bahkan kriminalisasi terhadap benda-benda cagar budaya dan sering kita lihat rendahnya minat masyarakat untuk datang ke museum untuk melihat dan mengapresiasi bendabenda cagar budaya bahkan perilaku yang tidak bangga terhadap benda-benda warisan budaya bangsa (Kuntjoro dalam Soebijantoro, 2013: 54).

Dengan adanya kasus-kasus tersebut, menambah catatan buruk mengenai kebijakan tata kelola kebendaan bersejarah di Indonesia. Peristiwa-peristiwa tersebut, mencerminkan bahwa Pemerintah kurang memperhatian akan perlindungan, pelestarian, dan perawatan mengenai keberadaan benda bersejarah. Karena benda bersejarah adalah gambaran nyata yang tersisa dari peradaban manusia terdahulu, dan bukti ragam budaya dari nenek moyang kita, yang perlu kita lestarikan. Maka dari itu dengan adanya hal-hal tersebut, perlunya pemerintah daerah harus benar-benar memperhatikan mengenai kebijakan tata kelola benda peninggalan bersejarah. Karena benda bersejarah merupakan aset yang berharga bagi Bangsa Indonesia yang perlu dijaga dan dilestarikan. Di samping itu perlunya penekanan akan pentingnya menjaga kelestarian sejarah nusantara bagi penerus bangsa ini, untuk proses pembelajaran bagi masa depan dan akan pentingnya mendalami ilmu sejarah khususnya peninggalan-peninggalanya. Oleh karena itu, nilai-nilai kehidupan masa lalu harus kita gali untuk menegakkan martabat bangsa kita sekarang, serta demi pembangunan masa depan. Mengingkari prestasi nenek moyang kita, berarti memalsu identitas kita sekarang, dan membangun atas dasar kepalsuan berarti menjerumuskan generasi yang akan datang (Soekmoro dalam Mahmud dan Mas'ud, 1989: 8)

Ponorogo merupakan salah satu kota yang memiliki sejarah yang panjang dari sejak dan sebelum berdirinya kota Ponorogo. Hal ini terbukti dari banyaknya penemuan-penemuan benda-benda peninggalan dari kehidupan masa lampau yang terdapat diberbagai tempat di Ponorogo. Belanda memuat cerita 4 zaman yaitu: 1 . Zaman Purbakala, yang disebut zaman prasejarah. Artinya zaman sebelum manusia dapat menyusun sejarah, 2. Zaman Wengker, 3. Zaman berdirinya Kadipaten Ponorogo dan datangnya agama Islam di Ponorogo, 4. Zaman Bangsa Indonesia di bawah kekuasaan penjajah Belanda, khususnya di daerah Kabupaten Ponorogo (Purwowijoyo, jilid vii 1985: 7).

Dari sejarah berdirinya kota Ponorogo, pada setiap masanya memiliki peninggalanpeninggalan sejarahnya, dimana dengan adanya ditemukan berbagai fosil-fosil manusia pada masa purbakala. Penemuan ini ditemukan di kaki Gunung Pandan, dan Kecamatan Sampung yang ditemukan fosil hewan, manusia, dan alat-alat purbakala pada Zaman Batu. Penemuan-penemuan benda-benda yang berasal dari masa kerajaanpun banyak ditemukan, seperti adanya penemuan arca-arca dan tempattempat atau situs dari masa kerajaan, Seperti penemuan arca Agsobhya (sikap Budha) yang ditemukan di Kadipaten pada tahun 1980, dan penemuan situs Watu Dukun yang 
diyakini merupakan peninggalan dari Empu Sendok dan masih banyak lagi.

Berbagai peninggalan sejarah tersebut tergolong dalam peninggalan imateri dan materi. Diamana yang termasuk peninggalan imateri merupakan peninggalan yang tidak berupa benda dan peninggalan materi adalah peninggalan yang berupa benda. Ponorogo memiliki banyak peninggalan sejarah yang berupa benda atau materi yang tersebar diberbagai wilayah di Ponorogo. Namun dari penemuan benda sejarah tersebut masih adanya ketidakmaksimalan pemerintah, dalam pemanfaatan, perlindungan, pelestarian benda cagar budaya atau situs sejarah. Benda peninggalan sejarah ini memiliki keterkaitan akan hukum, dimana hukum pidana mengenai benda cagar budaya sudah terkandung dalam UUD RI No. 11 tahun 2010 mengenai kebijakan akan perlindungan dan pelestarianya. Kebijakan pemerintah daerah akan perlindungan dan pelestraian benda peninggalan sejarah ini mutlak ditegaskan, karena akhir-akhir ini keberadaan benda bersejarah di Ponorogo ini mulai terancam.

Benda atau situs peninggalan bersejarah yang ditemukan di Ponorogo sangat beragam, seperti situs Watu Dukun yang ditemukan di Kecamatan Sumoroto desa Pager Ukir, dan situs peninggalan Kerajaan Medang yang terdapat di desa Sampung adalah sebagian situs yang terdapat di sebagian wilayah di Ponorogo. Benda atau situs cagar budaya tersebut masih belum sepenuhnya diekplorasi oleh Pemerintah Kabupaten Ponorogo. Contoh penemuan peninggalan situs sejarah tersebut hanya sebagian penemuan yang terdapat di wilayah Ponorogo, yang masih tergolong terdapat di area lingkup wilayah desa. Benda peninggalan sejarah yang terdapat di Kabupaten Ponorogo ini ada yang terurus dan, ada yang tidak terurus. Sehingga pertanyaan diantaranya bagaimana kebijakan Pemerintah Kabupaten Ponorogo terhadap pelestarian situs peninggalan sejarah. Untuk itu maka penelitian ini menarik untuk diteliti.

\section{Tujuan Penelitian}

Penulisan penelitian ini memiliki tujuan yang dicapai, sebab tujuan penelitian tersebut akan memberi arah ke dalam penelitian. Adapun yang menjadi tujuan penelitian ini adalah : Mengetahui kebijakan Pemerintah mengenai pelestarian benda peninggalan sejarah di Kabupaten Ponorogo.

\section{Kajian Pustaka}

\section{A. Kebijakan Pemerintah}

Istilah kebijakan disepadankan dengan kata (policy) yang dibedakan dengan kebijaksanaan (wisdom) maupun kebajikan (virtues). Winarno dan Wahab sepakat bahwa istilah kebijakan ini penggunaanya sering dipertukarkan dengan istilah-istilah lain seperti tujuan (goals), program, keputusan, undang-undang, ketentuanketentuan, standar, proposal dan grand design. Bagi para policy makers (pembuat kebijakan) dan orang-orang yang menggeluti kebijakan, peggunaan istilah-istilah tersebut tidak menimbulkan masalah, tetapi bagi orang di luar struktur pengambilan kebijakan tersebut mungkin akan membingungkan.

Pada dasarnya terdapat banyak batasan atau definisi mengenai apa yang dimaksud dengan kebijakan (policy). Setiap definisi tersebut memberi penekanan yang berbeda-beda. Perbedaan ini timbul karena setiap ahli mempunyai latar belakang yang berbeda-beda pula (Suharno, 2013: 2-3).

$$
\text { Ali dan Alam (2012: 3) }
$$
mengemukakan kebijakan pemerintah diramu dari dua konsep dasar, yaitu konsep kebijakan dan konsep pemerintah. Dua konsep yang mengandung makna satu kesatuan pengertian ketika masing-masing konsep diuraikan secara konseptual yang berujung pada satu kesatuan pengertian dalam konteks pemakaian yang berbeda.

Pemerintah yang menempatkan konteks kebijakan dalam pemberian makna atas arti terhadapnya pada hakikatnya menjadikan pemerintah sebagai suatu konsep menjadi sesuatu yang aktual, sesuatu yang tidak sekadar menjadi sesuatu yang dapat diaplikasikan, diterapkan dan 
menjadikan ia menjadi aktual dalam kehidupan pemerintah suatu negara.

Friedrich (dalam Suharno, 2013: 4) berpendapat bahwa kebijakan adalah suatu tindakan yang mengarah pada tujuan yang diusulkan oleh seseorang, kelompok atau pemerintah dalam suatu lingkungan tertentu sehubungan dengan adanya hambatanhambatan tertentu seraya mencari peluangpeluang untuk mencapai tujuan atau mewujudkan sasaran yang diinginkan.

Dye (dalam Islamy, 2009: 18) juga berpendapat bahwa kebijaksanaan negara sebagai "is whatever governments choose to do or to do" dapat diartikan bahwa apapun yang dipilih oleh pemerintah untuk dilakukan atau tidak dilakukan. Selanjutnya Dye mengatakan bahwa bila pemerintah memilih untuk melakukan sesuatu maka harus ada tujuanya (obyektifnya) dan kebijaksanaan negara itu harus meliputi semua tindakan pemerintah jadi bukan semata-mata merupakan pernyataan kengininan atau pejabat pemerintah saja. Di samping itu sesuatu yang tidak dilaksanakan oleh pemerintahan pun termasuk kebijakan negara. Hal ini disebabkan karena sesuatu yang tidak dilakukan oleh pemerintah akan mempunyai pengaruh (dampak) yang sama besarnya dengan sesuatu yang dilakukan oleh pemerintah.

Menurut konsep demokrasi modern, kebijaksanaan negara tidaklah hanya berisi cetusan pikiran atau pendapat para pejabat yang mewakili rakyat, tetapi opini publik (public opinion) juga mempunyai porsi yang sama besarnya untuk diisikan (tercermin) dalam kebijaksanaan-kebijaksanaan negara. Setiap kebijakan negara harus selalu berorientasi pada kepentingan publik (public interest) (Islamy, 2009: 10).

Pendapat lain juga diungkapkan oleh Budiarjo (dalam Ali dan Alam, 2012: 11) kebijaksanaan sebagai suatu kumpulan keputusan yang diambil oleh seseorang pelaku atau kelompok politik usaha memilih tujuan-tujuan dan cara-cara untuk mencapai tujuan, sedangkan keputusan adalah membuat pilihan di antara beberapa alternatif. Dalam kebijakan akan ditemukan sejumlah keputusan, dan setiap keputusan dikumpulkan maka hal itu akan terwujud sebagai suatu kebijakan. Perbedaan keduanya berada pada konteks operasional, yang pada hakikatnya mengandung arti yang sama yaitu adanya pilihan sejumlah laternatif yang dirumuskan dan atau yang diambil.

Raksasataya (dalam Islamy, 2009: 17-

18). Mengemukakan bahwa kebijakan sebagai suatu taktik dan strategi yang diarahkan untuk mencapai suatu tujuan. Oleh karena itu suatu kebijaksanaan memuat 3 (tiga) elemen yaitu identifikasi dari tujuan yang ingin dicapai, taktik atau strategi dari berbagai langkah untuk mencapai tujuan yang diinginkan dan penyediaan berbagai input untuk memungkinkan pelaksanaan secara nyata dari taktik atau sebuah strategi.

Berdasarkan beberapa pengertian dari para ahli akhirnya dalam suatu glossary dibidang adminitrasi negara, kebijakan diartikan sebagai berikut:

1. The organizing framework of purposes and rationales for government program that deal with specified societal problems (susunan rancangan tujuan-tujuan dan dasar-dasar pertimbangan programprogram pemerintah yang berhubungan dengan masalah-masalah tertentu yang dihadapi masyarakat).

2. Whatever governments choose to do or not to do (apapun yang dipilih pemerintah untuk dilakukan atau tidak dilakukan).

3. The complex programs enacted and implemented by government (maslahmasalah yang kompleks yang dinyatakan dan dilaksanakan oleh pemerintah) (Islamy, 2009: 20).

Dari beberapa pendapat di atas dapat disimpulkan pengertian kebijakan pemerintah bahwa kebijakan berasal dari adanya kepentingan umum dan terdiri dari adanya berbagai tujuan-tujuan untuk membawa ke arah yang ingin dicapai dan kebijakan didasarkan pada kepentingan umum yang berpusat pada pemerintah dan dilaksanakan atau tidak dilaksanakan oleh pemerintah untuk kepentingan umum maupun kepentingan bersama.

\section{B. Pelestarian Situs}

Dalam kamus besar bahasa Indonesia (2008: 820) pelestarian merupakan proses, cara, perbuatan melestarikan; perlindungan 
dari kemusnahan atau kerusakan; konservasi; sumber-sumber alam; pengelolaan sumberdaya alam yang menjamin kesinambungan persediaan dengan tetap memelihara dan meningkatkan kualitas nilai dan keanekaragaman.

Pelestarian adalah upaya dinamis untuk mempertahankan keberadaan Cagar Budaya dan nilainya dengan cara melindungi, mengembangkan dan memanfaatkannya (Undang-Undang Republik Indonesia Nomor. 11 Pasal 1 Ayat 22 Tahun 2010 Tentang Cagar Budaya, 2010: 5).

Menurut Balai Konservasi Peninggalan Borobudur (2008: 14) pelestarian adalah suatu tindakan aktif untuk membuat suatu obyek arkeologi agar obyek yang dimaksud tetap awet, aman dan terpelihara sepanjang masa. Dengan demikian pelestarian tidak hanya bersifat fisik, tetapi juga mencakup aspek-aspek lain yang bersifat non fisik.

Pelestarian menurut Prasetyo dan Wasito (2014: 84) adalah upaya perlindungan dari adanya bahaya kemusnahan agar tetap terjaga dan terawat keberadaanya. Perkembangan dan kemajuan tekhnologi semakin menggeser kebudayaan daerah. Sebagai generasi muda hendaknya ikut menjaga dan melestarikan budaya daerah karena budaya daerah merupakan akar dari munculnya budaya nasional.

Kusumohartono (dalam BKPB, 2009: 11) menyatakan bahwa pelestarian merupakan kegiatan penting dan utama, sebab tanpa pelestarian maka kegiatan pembinaan dan pemanfaatan tidak dapat dilaksanakan. Oleh karena itu, upaya pelestarian penyelamatan data pelestarian sumberdaya arkeologi perlu mendapat perhatian utama untuk dikembangkan dan dimasyarakatkan.

Dengan demikian pelestarian situs adalah suatu tindakan, usaha atau kegiatan untuk mengupayakan perawatan untuk melindungi, melestarikan dan memanfaatkan, pelestarian ditujukan untuk memajukan kepentingan bersama bertujuan untuk kepentingan yang bermanfaat guna mengembangkan peninggalan sejarah untuk kepentingan ilmu pendidikan.

\section{Peninggalan Sejarah atau Situs Cagar Budaya}

Sutrasno (1975: 7-8) memberikan pendapat sebagai berikut:

a. bahwa yang dimaksud dengan sejarah ialah segala kejadian sepanjang masa. Segala kejadian, tidak berarti bahwa semua kejadian dicatat dalam sejarah, tetapi yang terbatas yang ada hubunganya dengan tata kehidupan dengan manusia.

b. Peristiwa sejarah bukanlah kejadian atau peristiwa perseorangan, artinya yang tidak menyangkut sebagian besar orang (manusia), sehingga dengan kejadian itu tidak dapat menimbulkan perubahan struktur ekonomi, sosial, politik dan kebudayaan dari pada sekelompok manusia yang hidup di daerah yang dalam batasbatas tertentu cukup luas.

c. Sejarah adalah segala kegiatan manusia dan segala kejadian yang ada hubunganya dengan kegiatan manusia sedemikian rupa sehingga mempunyai akibat adanya perubahan politik, sosial, ekonomi dan kebudayaan, dan kesemuanya ditinjau dari sudut perkembanganya (berjalan dalam tempat dan waktu, atau adanya saling hubungan dalam tempat dan waktu).

Dalam Undang-Undang Republik Indonesia Nomor. 11 Tahun 2010 Tentang Cagar Budaya Pasal 1 dijelaskan cagar budaya adalah warisan budaya yang bersifat kebenaran yang berupa benda cagar budaya, bangunan cagar budaya, struktur cagar budaya, situs cagar budaya, dan kawasan cagar budaya di darat dan/atau di air yang perlu dilestarikan keberadaanya karena memiliki nilai penting bagi sejarah, illmu pengetahuan, pendidikan, agama, dan/atau kebudayaan melalui proses penetapan. Dan juga disebutkan bahwa yang dimaksud situs cagar budaya adalah lokasi yang berada di darat/atau di air yang mengandung benda cagar budaya, bangunan cagar budaya, dan/atau struktur cagar budaya sebagai hasil kegiatan manusia atau kejadian pada masa lalu.

Berkala Arkeologi (1993: 87) menyatakan pengertian situs dalam Undangundang Republik Indonesia Nomor 5 Tahun 1992 tentang benda cagar budaya pada pasal 1, butir 2 disebutkan bahwa situs adalah 
lokasi yang mengandung atau diduga mengandung benda cagar budaya termasuk lingkungan yang diperlukan bagi pengamanannya. Selain itu suatu hal penting yang perlu diketengahkan ialah bahwa situs adalah sebagai sumberdaya yang terbatas (infinite), tak terbaharui (non renewable), tak dapat dipindahkan (non moveable)dan rapuh (vulnerable/fragile), sehingga diperlukan penanganan situs secara tepat dan benar.

Terdapat banyak istilah yang sering digunakan oleh masyarakat untuk menyebutnya, mulai dari benda kuno, barang antik hingga peninggalan arkeologi (archaeological remains). Namun kalau kita merujuk pada Undang-undang No 5 tahun 1992 tentang Benda Cagar Budaya (BCB) maka akan spesifik yaitu benda cagar budaya bergerak dan tidak bergerak. Secara khusus dijelaskan bahwa untuk benda cagar budaya bergerak berupa kesatuan atau kelompok atau bagian-bagian atau sisanya yang berumur sekurang-kurangnya 50 (limapuluh) tahun atau mewakili masa gaya sekurang-kurangnya 50 (limapuluh) tahun serta dianggap mempunyai nilai penting bagi sejarah, ilmu pengetahuan dan kebudayaan. Sedangkan benda cagar budaya tidak bergerak berupa benda alam yang dianggap mempunyai nilai penting bagi sejarah ilmu pengetahuan dan kebudayaan. (Soebijantoro, 2013: 55).

Menurut BKPB (2009: 11) bahwa sumberdaya arkeologi atau benda cagar budaya beserta situsnya adalah sisa-sisa hasil budaya fisik peninggalan nenek moyang yang masih dapat dilihat di muka bumi sampai saat ini. Sumberdaya arkeologi merupakan warisan budaya dan merupakan data yang sangat penting untuk rekontruksi sejarah serta mengetahui proses perubahan masa lalu.

Mahmud dan Mas'ud (2012: 4-5) mengungkapkan bahwa sumberdaya arkeologi adalah bagian dari bagian sumberdaya budaya. Pengertian sumberdaya adalah segala sesuatu, atau sejumlahan dari sesuatu yang merupakan khasanah bermakna bagi segala macam upaya berkaitan dengan kebudayaan, baik dalam pengembangaannya, perlindungannya, pemanfaatannya, maupun pengkajian- nya. Selain itu ada juga yang mendefinisikan sumberdaya budaya (SDB) sebagai gejala fisik, baik ilmiah maupun buatan manusia, yang memiliki nilai penting bagi sejarah, arsitektur, arkeologi dan pengembangan budaya yang diwariskan hingga saat ini, bersifat unik dan tidak terperbaharui (nonrenewable). Definisi tersebut menegaskan bahwa di dalam sumberdaya budaya (SDB) termasuk di dalamnya sumberdaya arkeologi (SDA). Dengan demikian parameter sebuah sumberdaya arkeologi meliputi:

1. Memiliki nilai sejarah, baik lokal, regional maupun internasional;

2. Mengandung nilai-nilai kepurbakalaan (arkeologi);

3. Memiliki hubungan/keterkaitan dengan perkembangan kebudayaan manusia;

4. Memiliki sesuatu yang unik dan khusus; serta

5. Tidak mungkin untuk diperbaharui

Sebagaimana dari sumberdaya budaya, parameter tersebut di atas tercermin dalam sifat khas sumberdaya arkeologi (SDA), seperti:

1. Jumlah dan keberadaanya sangat terbatas;

2. Tidak terperbaharu (non-renewable);

3. Memiliki sesuatu yang unik dan khas; serta

4. Sulit dideteksi keberadaanya.

Pendapat lain juga diungkapkan oleh Rokhmani (dalam BKPB, 2008: 3) Benda Cagar Budaya didefiniskan sebagai benda tinggalan masa lalu yang bernilai peting artinya bagi pengembangan ilmu pengetahuan, sejarah dan kebudayaan, sehingga perlu dilindungi dan dilestarikan demi memupuk jati diri bangsa dan kepentingna nasional.

Berdasarkan beberapa pendapat di atas yang dimaksud peninggalan sejarah atau benda cagar budaya adalah suatu sisasisa kegiatan manusia pada masa lampau, yang menciptakan suatu hasil dari tinggalan nenek moyang kita memiliki nilai budaya dan historis yang tidak ternilai, menunjukan jati diri bangsa, serta memiliki manfaat dalam kajian ilmu pendidikan yang perlu dimanfaatkan dan dilestarikan. 


\section{Metode Penelitian}

Penelitian ini dilaksanakan di Kabupaten Ponorogo. Hal ini dikarenakan di Kabupaten Ponorogo banyak terdapat situs peninggalan-peninggalan sejarah yang tersebar di wilayah-wilayah Kabupaten Ponorogo. Penelitian ini dilaksanakan selama 6 bulan yaitu mulai bulan Februari sampai Juli 2015.

Penelitian ini menggunakan pendekatan kualitatif. Pendekatan kualitatif merupakan metode penelitian yang digunakan untuk meneliti pada kondisi obyek yang alamiah, dimana peneliti adalah sebagai instrumen utama, teknik pengumpulan data dilakukan secara trianggulasi, analisis data bersifat induktif, dan hasil penelitian kualitatif menekan pada makna (Sugiyono, 2008: 205). Pada dasarnya penelitian kualitatif digunakan dalam penelitian yang merujuk pada objek dan fenomena yang terjadi secara alami. Adapun data yang akan diperoleh akan bersifat deskriptif karena menggunakan pendekatan induktif.

Dalam penelitian ini menggunakan pendekatan induktif dimana peneliti melakukan pengamatan atas permasalahan kebijakan perlindungan dan pelestarian benda peninggalan sejarah yang ada di Kabupaten Ponorogo. Kemudian menarik kesimpulan secara umum dengan dukungan dari beberapa informasi, sehingga data yang akan diperoleh akan bersifat deskriptif.

Jenis penelitian yang dilakukan yaitu jenis penelitian deskriptif. Bagian deskriptif dalam catatan data ini meliputi potret subjek, rekonstruksi dialog, deskripsi keadaan fisik, struktur tentang tempat, dan barang-barang lain yang ada di sekitarnya. Demikian juga, catatan tentang berbagai peristiwa khusus (termasuk siapa yang terlibat dengan cara bagaimana, gerakgeriknya, dan juga tingkah laku atau sikap penelitiannya) (Sutopo, 2002: 74).

Pendekatan ini cocok untuk meneliti tentang kebijakan Pemerintah yang ada di Kabupaten Ponorogo dalam pelestarian peninggalan sejarah, benda cagar budaya maupun situs yang ditemukan diberbagai wilayah-wilayah Kota Ponorogo. Penelitian ini dilaksanakan dengan menganalisis data yang diperoleh dari wawancara, dokumentasi, dan observasi langsung di lapangan.

Sumber utama dalam penelitian kualitatif ialah kata, dan tindakan, selebihnya adalah data tambahan seperti dokumen dan lain-lainnya. Menurut Sugiono (2013: 137), sumber data dapat dilakukan dalam berbagai setting, berbagai sumber dan berbagai cara. Bila dilihat dari setting-nya, data dapat dikumpulkan pada setting alamiah ( natural setting ), Sumber data penelitian ini merupakan sumber data primer dan sumber data sekunder yang dapat menjelaskan informasi yang diperlukan dalam penelitian. Sumber data pada penulisan ini diperoleh dari:

1. Sumber Data Primer

Sumber data primer merupakan sumber data yang langsung memberikan data kepada pengumpul data (Sugiono, 2001: 129). Hal senada juga disampaikan oleh Umar (2011: 42) bahwa data primer merupakan data yang diperoleh dari sumber pertama baik dari individu atau perseorangan seperti hasil dari wawancara atau hasil pengisian kuisioner yang biasa dilakukan oleh peneliti.

Data yang didapat berupa hasil wawancara dengan informan. Sumber lisan ini dapat diperoleh dengan mendeskripsikan secara tertulis hasil dari pengamatan atau wawancara serta dokumentasi yang dilakukan. Informan dari penelitian ini yaitu Dinas Kebudayaan Pariwisata Pemuda dan Olahraga (DIKEBPARPORA), BAPEDA, juru kunci di setiap situs/cagar budaya yang ada di Ponorogo, sesepuh serta masyarakat Kabupaten Ponorogo yang dipilih secara selektif.

2. Sumber Data Sekunder

Sumber data sekunder menurut Sugiono (2013: 137) adalah sumber yang tidak langsung memberikan data kepada pengumpul data. Sumber data sekunder yang digunakan dalam penelitian ini adalah Peraturan Kebijakan tentang adanya benda peninggalan sejarah, data yang diperoleh dari Dinas Kebudayaan Pariwisata Pemuda dan Olahraga (DIKEBPARPORA) Kabupaten Ponorogo, berupa sumber data tertulis 
berasal dari arsip, dokumen, serta bukubuku yang diperoleh dari adanya penemuan benda peninggalan sejarah yang ada di Kabupaten Ponorogo.

Pengumpulan data dalam penelitian ini dilakukan dengan wawancara, observasi, dan dokumentasi tertulis atau arsip.

1. Wawancara

Sukmadinata (2012: 216) berpendapat bahwa wawancara atau interviu (interview) merupakan salah satu bentuk teknik pengumpulan data yang banyak digunakan dalam penelitian deskriptif kualitatif dan deskriptif kuantitatif. Wawancara dilaksanakan secara lisan dalam pertemuan tatap muka secara individual. Adakalanya juga wawancara dilakukan secara kelompok, kalau memang tujuanya untuk menghimpun data dari kelompok seperti wawancara dengan satu keluarga, pengurus yayasan, atau Pembina pramuka. Hal serupa juga diungkap oleh Esterberg (dalam Sugiyono, 2008: 231) wawancara adalah pertemuan dua orang untuk bertukar informasi dan ide melalui tanya jawab, sehingga dapat dikonstruksikan makna dalam suatu topik tertentu.

Wawancara (interview) dikelompokkan menjadi beberapa bentuk dalam melakuakan komunikasi lisan yaitu berupa bentuk terstruktur, semiterstruktur, dan tidak terstruktur (Sugiyono, 2008: 233). Penelitian yang dilakukan menggunakan jenis wawancara tidak terstruktur. Artinya pedoman wawancara yang digunakan berupa garis-garis besar permasalahan yang akan digunakan.

Penggunaan metode tersebut karena peneliti akan melakukan wawancara kepada informan yang dianggap sebagai salah satu sumber yang bisa menjawab masalah penelitian. Peneliti pun perlu menjelaskan kepada responden tentang maksud dan tujuan penelitian ini. Sebelum mengadakan wawancara terlebih dahulu peneliti menyusun pedoman wawancara. Metode tersebut akan mampu menjawab kebijkan Pemerintah Kabupaten Ponorogo dalam pelestarian situs peninggalan sejarah tahun 2000-2015.

2. Observasi Langsung
Menurut Hadi (dalam Sugiyono, 2013: 145) menyatakan bahwa observasi adalah suatu proses yang kompleks, suatu proses yang tersusun dari pembagian proses biologis dan psikologis. Dua di antara yang terpenting adalah proses-proses pengamatan dan ingatan.

Hal senada juga disampaikan oleh Nazir (2009: 175) observasi langsung atau dengan pengamatan langsung adalah cara pengambilan data dengan menggunakan mata tanpa ada pertolongan alat standar lain untuk keperluan tersebut. Teknik observasi digunakan untuk menggali data dari sumber data yang berupa peristiwa, tempat atau lokasi dan benda serta tekanan gambar yang dilakukan secara langsung maupun tidak langsung.

Observasi yang dilakukan dalam penelitian ini adalah peneliti mengamati keberadaan situs peninggalan sejarah di Kabupaten Ponorogo guna mengetahui Kebijakan pelestariannya. Dalam observasi ini peneliti mendatangi lokasi dan mengamati secara langsung maupun tidak langsung lewat paparan data mengenai kondisi aktual yang ada di setiap situs peninggalan sejarah di Kabupaten Ponorogo.

3. Dokumentasi Tertulis/Arsip

Menurut Sugiyono (2006: 329) menyatakan bahwa dokumen merupakan catatan peristiwa yang sudah berlalu. Dokumen biasanya bisa berbentuk tulisan, gambar, atau karya-karya monumental dari seseorang. Dokumen berbentuk tulisan misalnya, catatan harian, sejarah kehidupan, ceritera, biografi, peraturan, kebijakan. Dokumen berbentuk gambar, misalnya, foto, gambar hidup, sketsa, dan lain-lain. Dokumen yang berbentuk karya misalnya, karya seni, yang dapat berupa gambar, patung, film, dan lain-lain. Studi dokumen merupakan pelengkap dari penggunaan metode observasi dan wawancara dalam penelitian kualitatif.

Dokumen merupakan sumber data yang sering memiliki posisi penting dalam penelitian kualitatif. Terutama bila sasaran kajian mengarah pada latar belakang atau berbagai peristiwa yang terjadi di masa lampau dan berkaitan dengan kondisi atau peristiwa masa kini. Dokumen bisa memiliki 
beragam bentuk, dari yang tertulis sederhana sampai yang lebih lengkap, dan bahkan bisa berupa benda-benda lainnya sebagi peninggalan masa lampau (Sutopo, 2002: 69).

Teknik analisis isi dokumen digunakan untuk memperoleh data atau informasi yang bersumber dari dokumen atau arsip yang berupa buku tentang penemuan situs peninggalan sejarah di Kabupaten Ponorogo dan kebijakan Pemerintah mengenai pelestariannya.

Dalam penelitian kualitatif, yang menjadi instrumen atau alat penelitian adalah peneliti itu sendiri (Sugiono,2012 : 305).

Dalam penelitian kualitatif instrumen utamanya adalah peneliti itu sendiri, namun selanjutnya setelah fokus penelitian menjadi jelas, maka kemungkinan akan dikembangkan instrumen penelitian sederhana, yang diharapkan dapat melengkapi data, dan membandingkan dengan data yang telah ditemukan melalui observasi dan wawancara (Sugiono, 2012: 307).

Penelitian ini tentang Kebijakan Pemerintah Kabupaten Ponorogo dalam pelestarian peninggalan situs sejarah tahun 2000-2015 dilakukan selama 6 bulan. Penelitian dilaksanakan mulai dari bulan Februari sampai dengan bulan Juli tahun 2015. Tahapan dalam penelitian ini tersusun sebagai berikut:

1. Tahap Persiapan

Tahap awal dari penelitian ini merupakan bagian dari menetapkan fokus penelitian. Kegiatan ini dimulai dengan menetapkan tema dan judul yang akan menjadi obyek penelitian. Termasuk didalamnya yaitu dengan menentukan lokasi penelitian. Selain itu peneliti juga melakukan perijin kepada pengelola obyek tersebut. Hal ini dilakukan agar tidak menimbulkan perbedaan pemahaman antara peneliti dan subyeknya. Selain itu juga mempermudah prosedur dalam melakukan penelitian selanjutnya.

Kemudian setelah menentukan tema dan judul, peneliti berkonsultasi tentang tema dan judul tersebut kepada dosen pembimbing. Selanjutnya juga menjelaskan tentang kondisi awal dari obyek penelitian. Setelah mendapatkan persetujuan maka peneliti mulai melakukan kegiatan penelitian awal.

\section{Tahap Penelitian}

Tahapan yang selanjutnya merupakan tahapan penelitian. Pada tahapan ini dilakukan pengumpulan data, pengolahan data, dan analisis data. Dalam tahapan pengumpulan data peneliti mendapatkan data dari berbagai sumber. Sumber yang didapat merupakan hasil dari wawancara, sumber dokumen, dan pengamatan atau observasi secara langsung.

Dengan begitu data yang terkumpul akan mampu diolah secara baik dan benar oleh peneliti. Pengolahan data digunakan untuk mendapatkan deskripsi awal obyek penelitian. Setelah itu dilakukan analisis data untuk mempermudah dan mendapatkan validitas dari hasil data yang diperoleh.

Tujuan analisis data memperdalam hasil temuan data yang diperoleh dan mampu mengetahui hasil awal sesuai dengan tujuannya. Jika diketemukan hasil yang kurang sesuai maka akan dilakukan analisis yang berkelanjutan. Hal ini dilakukan agar hasil penelitian benar-benar maksimal dan sesuai kenyataan.

3. Tahap Laporan

Pada tahap akhir merupakan tahap penyelesaian laporan atau penyajian data. Penyusunan laporan didasarkan pada hasil analisis data yang sudah didapatkan pada tahap sebelumnya. Laporan atau sajian dilakukan secara benar dan tersusun sistematis. Selain itu data yang disajikan merupakan data yang sesuai dengan fakta dan dapat dipertanggung jawabkan kebenarannya.

Kesalahan dalam laporan penelitian umumnya dilakukan yaitu laporan yang tidak tersusun secara sistematis dan penyajian data kesimpulan tidak sesuai dengan fakta yang didapat pada saat penelitian. Untuk menghindari hal tersebut penyajian data harus sesuai dengan analisis data yang dilakukan. Ini berarti peneliti harus benar-benar teliti dan mampu untuk dapat menyajikan data secara aktual. 
Untuk mendapatkan data yang valid dalam penelitian ini, peneliti menggunakan teknik validitas data sebagai berikut:

1. Triangulasi metode adalah pengumpulan data yang sama dengan menggunakan metode pengumpulan data yang berbeda, serta diusahakan mengarah pada sumber data yang sama untuk menguji kemantapan informasi. Penggunaan metode pengumpulan data yang berbeda, dan bahkan lebih jelas untuk diusahakan mengarah pada sumber data yang sama untuk menguji kemantapan informasinya. Misalnya, untuk memantapkan validitas data mengenai suatu keterampilan seseorang dalam bidang tertentu. Peniliti bisa menggunakan metode pengumpulan data yang berupa kuesioner. Kemudian dilakukan wawancara mendalam pada informan yang sama dan hasilnya diuji dengam pengumpulan data sejenis dengan menggunakan teknik observasi pada saat orang tersebut melakukan kegiatannya atau perilakunya (H.B. Sutopo, 2002: 80).

2. Triangulasi sumber data adalah mengumpulkan data dari berbagai sumber data digunakan untuk menguji kebenaran tentang pelaksanaan pembelajaran bahasa Indonesia. Cara ini mengarahkan peneliti agar di dalam mengumpulkan data, ia wajib menggunakan beragam sumber data yang tersedia. Artinya, data yang sama atau sejenis, akan lebih mantap kebenarannya bila digali dari beberapa sumber data yang berbeda. Triangulasi sumber data yang memanfaatkan jenis sumber data yang berbeda-beda untuk menggali data yang sejenis (H.B. Sutopo, 2002: 79).

3. Reviu informan merupakan usaha pengembangan validitas penelitian. Digunakan untuk mereviu informan, apakah data hasil wawancara sudah valid dan sesuai dengan kesepakatan atau belum. Pada waktu peneliti sudah mendapatkan data yang cukup lengkap dan belum utuh dan menyeluruh, maka unit-unit laporan yang telah disusunnya perlu dikomunikasikan dengan informannya, khususnya yang dipandang sebagai informan utama (H.B Sutopo, 2002: 83).

Analisis data seperti pendapat Lexy J.Moleong (2011: 247) adalah proses analisis data dimulai dengan menelaah seluruh data yang tersedia dari berbagai sumber yaitu wawancara, pengamatan yang sudah dituliskan dalam catatan lapangan, dokumen pribadi, dokumen resmi, gamba, foto, dan sebagainya.

Sedangkan Miles dan Huberman (dalam Sugiyono, 2008: 246-253) mengemukakan bahwa dalam analisis data kualitatif dilakukan secara interaktif dan berlangsung secara terus menerus melalui reduksi data (data reduction), penyajian data (data display) dan penarikan kesimpulan (conclusion drawing atau verification).

1. Tahap Reduksi Data

Dalam tahap reduksi data, peneliti melakukan proses seleksi, pemfokusan, penyederhanaan dan abstraksi data dari sumber penelitian. Reduksi data merupakan bagian dari proses analisis yang mempertegas, memperpendek, membuat fokus, membuang hal-hal yang tidak penting dan mengatur data sedemikian rupa sehingga simpulan penelitian dapat dilakukan. Peneliti melakukan tahap reduksi data dengan membaca secara cermat objek penelitian dan kemudian dibagi ke dalam kategori sesuai kajian yang peneliti amati.

2. Tahap Penyajian Data

Sajian data merupakan suatu rakitan organisasi informasi, deskripsi dalam bentuk narasi yang memungkinkan simpulan penelitian dapat dilakukan. Sajian ini merupakan rangkaian kalimat yang disusun secara logis dan sistematis. Tujuannya agar peneliti bisa memahami objek yang diteliti dan memberikan jawaban sesuai rumusan masalah penelitiannya. Hubungannya dengan tahap penyajian data, peneliti melakukan ringkasan yang relevan dengan bidang kajian yang diteliti. Hal ini dilakukan agar memudahkan peneliti dalam mengelompokkan dan menentukan simpulan.

3. Tahap Penarikan Kesimpulan

Tahap simpulan merupakan tahap akhir dalam analisis data ini. Berbagai data yang dibutuhkan untuk penarikan suatu simpulan mulai dianalisis secara lebih mendalam. Hal ini dilakukan agar penelitian kualitatif ini bisa dipertanggungjawabkan kebenarannya. Di samping itu, adanya data- 
data yang dikumpulkan dapat dijadikan suatu pertimbangan yang akan menentukan arah suatu kajian yang diteliti.

Oleh karena itu dalam tahapan yang dilakukan merupakan suatu rangkaian tahapan yang memiliki keterkaitan. Adapun keterkaitan komponen antara tahap tersebut sebagai berikut:

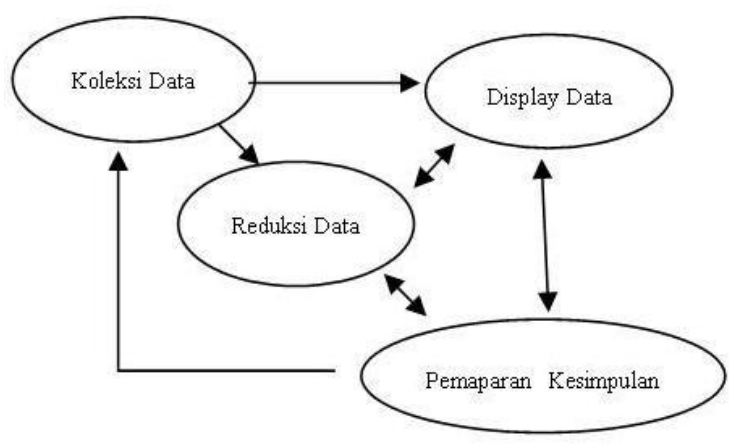

Bagan 3.2.

Analisis Data Model Interaktif, Miles dan Huberman (Miles dan Huberman, 1992: 20)

\section{Hasil Penelitian dan Pembahasan}

\section{A. Kebijakan Pemerintah Ponorogo Dalam Pelestarian Situs Peninggalan Sejarah}

Kebijakan pemerintah Kabupaten Ponorogo mengenai pelestarian situs peninggalan sejarah mengacu pada UndangUndang Republik Indonesia Tentang Benda Cagar Budaya No. 11 Tahun 2010, yang sebelumnya menggunakan acuan UUD RI BCB No. 05 Tahun 1992. Termuat dalam UUD RI No. 11 Tahun 2010 tentang benda cagar budaya diantarannya mengacu pada poin-poin pembukaan berikut:

1. Bahwa benda cagar budaya merupakan kekayaan budaya bangsa sebagai wujud pemikiran dan perilaku kehidupan manusia yang penting artinya bagi pemahaman dan pengembangan sejarah, ilmu pengetahuan, dan kebudayaan dalam kehidupan bermasyarakat, berbangsa dan bernegara sehingga perlu dilestarikan dan dikelola secara tepat melalui upaya perlindungan, pengembangan, dan pemanfaatan dalam rangka memajukan kebudayaan nasional untuk sebesar-besarnya kemakmuran rakyat.

2. Bahwa untuk melestarikan cagar budaya, negara bertanggung jawab dalam pengaturan perlindungan, pengembangan, dan pemanfaatan cagar budaya.

3. Bahwa cagar budaya berupa benda, bangunan, struktur, situs, dan kawasan perlu dikelola oleh pemerintah dan pemerintah daerah dengan meningkatkan peran serta masyarakat untuk melindungi, mengembangkan, dan memanfaatkan cagar budaya.

4. Bahwa dengan adanya perubahan paradigma pelestarian cagar budaya, diperlukan keseimbangan aspek ideologi, akademis, ekologis, dan ekonomis guna meningkatkan kesejahteraan masyarakat.

5. Bahwa Undang-Undang No. 5 Tahun 1992 tentang Benda Cagar Budaya sudah tidak sesuai dengan perkembangan, tuntutan, dan kebutuhan hukum dalam masyarakat sehingga perlu diganti.

6. Bahwa berdasarkan pertimbangan sebagaimana dimaksud dalam poin 1 , poin 2 , poin 3 , poin 4 , poin 5 perlu membentuk Undang-Undang tentang cagar budaya.

Berdasarkan dari poin-poin di atas pemerintah Kabupaten Ponorogo tentunya memperhatikan sekali dengan keberadaan peninggalan situs sejarah tersebut. Mengingat Kabupaten Ponorogo dari sejarahnya memiliki sejarah yang panjang dari masa ke masa. Berawal dari masa purbakala, kerajaan Hindu-Budha, dan masuknya Islam di Ponorogo. Dari masamasa tersebut Kabupaten Ponorogo memiliki peninggalan sejarah yang banyak, yang tersebar di wilayah-wilayah Ponorogo.

$$
\text { Namun pada kenyataannya }
$$
penanganan kebijkakan pemerintah Kabupaten Ponorogo dalam melestarikan baik menjaga, merawat adanya situs peninggalan sejarah kurang maksimal. Dalam kurun waktu beberapa tahun kurang lebih 14 tahun ini, adanya kasus-kasus yang berkaitan dengan kebendaan sejarah marak terjadi. Kurangnya perhatian, perawatan, penanganan yang kurang serius, hingga kasus pencurian benda bersejarah sering terjadi. Terdapat arca yang pengelolaannya tidak sesuai dengan prosedur perawatan 
juga ditemukan, seperti terdapatnya pengecatan pada arca. Jelas hal ini tidak dibenarkan dalam perawatan kebendaan purbakala.

Pada tahun 2002 pemerintah Kabupaten Ponorogo kehilangan kurang lebih 13 arca, adapun arca-arca yang hilang seperti arca kerbau, arca Ganesha, dan arca miniatur rumah. Kejadian ini terjadi ketika pemerintah Kabupaten Ponorogo membangun gedung tingkat 8 atau saat ini yang dikenal gedung PEMKAB, dan juga adanya kasus-kasus lain pelaporan dari masyarakat Ponorogo. Dengan adanya kasus-kasus ini kebijakan pemerintah Kabupaten Ponorogo terkesan kurang maksimal dan lamban. Jika mengacu pada UUD RI tentang benda cagar budaya sudah jelas Kabupaten Ponorogo dengan penggunaan UUD BCB sebelumnya hanya sebatas wacana.

Kejadian kasus tersebut juga tidak lepas dari adanya faktor-faktor yang melatar belakangi kurang maksimalnya kebijakan pemerinatah Kabupaten Ponorogo dalam pelestarian situs peninggalan sejarah. Berbagai faktor yang menjadi kendala yaitu yang pertama adalah masalah anggaran untuk pendanaan perawat maupun pelestarian situs, Pengelolaan yang kurang maksimal maupun penataan ruang dari pemerintah daerah terhadap situs peninggalan sejarah. Keterbatasan mengenai tenaga ahli. Dan juga adanya unsur mistis maupun klenik dari masyarakat sekitar situs. Dari berbagai permasalahan tersebut tidak jauh dari kurangnya penataan ruang, baik tranparansi kebijakan yang dilaksanakan oleh Pemerintah Ponorogo Dalam pendataan untuk keterangan situs di Kabupaten Ponorogo belum ada pembukuan, pemerintah baru mengupayakan penyusunan mengenai data-data situs maupun benda-benda cagar budya. Hal memperburuk sistem penataan tata ruang situs bersejarah di Ponorogo, dan mempersulit pendataan situs jikalau ada penemuan maupun situs peninggalan sejarah.

Baru beberapa kurun waktu 2 sampai 3 tahun ini pemerintah mulai menyadari pentingnya memperhatikan pengelolaan situs peninggalan sejarah ini. Mengingat Kebijakan merupakan satu kesatuan dari konsep pemerintahan yang perlu adanya keseriusan pengelolaannya. Hal ini sangat relevan sekali seperti yang diungkapkan oleh Ali dan Alam (2012: 3) mengemukakan kebijakan pemerintah diramu dari dua konsep dasar, yaitu konsep kebijakan dan konsep pemerintah. Dua konsep yang mengandung makna satu kesatuan pengertian ketika masing-masing konsep diuraikan secara konseptual yang berujung pada satu kesatuan pengertian dalam konteks pemakaian yang berbeda.

Pemerintah yang menempatkan konteks kebijakan dalam pemberian makna atas arti terhadapnya pada hakikatnya menjadikan pemerintah sebagai suatu konsep menjadi sesuatu yang aktual, sesuatu yang tidak sekadar menjadi sesuatu yang dapat diaplikasikan, diterapkan dan menjadikan ia menjadi aktual dalam kehidupan pemerintah suatu negara. Langkah pemerintah untuk mengupayakan pengelolaan situs peninggalan sejarah yang layak, dirintis oleh adanya dukungan kepedulian dari masyarakat. Kepedulian yang muncul karena cermin kinerja kebijakan pemerintah yang kurang tegas. Salah satunya dengan dibangunnya Balai Penyelamatan Benda Cagar Budaya yang sederhana. BPBCB ini dibangun dengan memakai bangunan bekas SDN di Desa Kertosari, yang terletak di Jln. Ukel No. 20 Desa Kertosari tepatnya di Balai Desa Kertosari. Balai Penyelamatan Benda Cagar Budaya (BPBCB) dinaungi langsung oleh Dinas Kebudayaan Pariwisata Pemuda dan Olahraga (DINKEBPARPORA) pemerintah Kabupaten Ponorogo yang mulai dibentuk kurang lebih 3 tahun ini.

Benda peninggalan sejarah yang diletakan di BPBCB Ponorogo ini hanya terdapat beberapa arca saja, yaitu sejumlah 14 yang merupakan pindahan dari beberapa wilayah di Ponorogo. Terutama arca-arca yang tadinya terdapat di area pusat pemerintahan Kabupabaten Ponorogo, di area dimana 13 arca dilaporkan hilang. Arca yang yang terdapat di BPBCB ini diantaranya arca 6 replika rumah, 2 replika gapura, 2 
yoni, 5 patung yang diduga perwujudan dewa siwa, dan 1 pecahan gerabah.

$$
\text { Untuk program kedepanya }
$$

pemerintah Kabupaten Ponorogo khususnya Dinas Kebudayaan Pariwisata Pemuda dan Olahraga (DINKEBPARPORA) merencanakan adanya pembangunan dalam pengupayaan penataan situs maupun benda peninggalan sejarah yang ada di Kabupaten Ponorogo, yakni dengan pengadaan museum. Hal ini karena Kabupaten Ponorogo dari tinjauan wilayahnya merupakan daerah yang berpotensi, khususnya dalam segi sumber daya alamnya. Mengingat dari sejarahnya Kabupaten Ponorogo memiliki sejarah yang panjang. Dimulai dari zaman purbakala, zaman kerajaan wengker, zaman berdirinya Kadipaten, dan zaman masuknya Islam di Ponorogo. Dari terbaginya zaman sejarah yang ada di Kabupaten Ponorogo tersebut tidak dipungkiri lagi bahwa masih banyak adanya peninggalan-peninggalan sejarah yang tedapat diwilayah Kabupaten Ponorogo

B. Tujuan Pelestarian Situs Peninggalan Sejarah

Pada umumnya tujuan daripada pelestarian situs peninggalan sejarah tertulis dalam UUD RI No. 11 Pasal 3, Tahun 2010 bahwa pelestarian Cagar Budaya bertujuan untuk melestarikan warisan budaya bangsa dan warisan umat manusia, meningkatkan harkat dan martabat bangsa melalui cagar budaya, memperkuat kepribadian bangsa, meningkatkan kesejahteraan rakyat dan mempromosikan warisan budaya bangsa kepada masyarakat nasional.

Seperti halnya tujuan pemerintah Kabupaten Ponorogo yang mengupayakan pelestarian, perawatan situs peninggalan sejarah. Adalah hal yang perlu diperhatikan berhubungan dengan pelestarian situs peninggalan sejarah. Karena situs baik benda peninggalanya keberadaannya sangat rawan, baik dari keamanan baik kelestariannya. Disamping rawanya kasuskasus pencurian pemerintah dan masyarakat, mengupayakan agar barangbarang yang sangat berharga ini bisa terawat dengan baik dan berguna untuk dimanfaatkan. Merelokasi benda-benda peninggalan ini agar ditempatakan di tempat yang layak termasuk juga tujuan untuk menjaga keberadaan peninggalan sejarah tersebut. Yang utama adalah agar terhindarnya dari kasus pencurian, kerusakan dan penanganan pelestarian itu sendiri.

Karena situs baik benda peninggalan sejarah merupakan bukti nyata yang tersisa dari sejarah nenek moyang kita, yang perlu kita rawat dan kita jaga akan keberadaanya. Benda peninggalan situs sejarah termasuk dalam warisan dunia yang wajib kita jaga dan termasuk dalam aset daerah. Warisan dari peradaban manusia pada masa lampau ini tak ternilai harganya, disamping itu juga, situs baik peninggalanya memiliki manfaat yang berguna bagi masyarakat umum.

Hal ini sesuai dengan apa yang dimaksud menurut Balai Konservasi Peninggalan Borobudur (2008: 14) pelestarian adalah suatu tindakan aktif untuk membuat suatu obyek arkeologi agar obyek yang dimaksud tetap awet, aman dan terpelihara sepanjang masa. Dengan demikian pelestarian tidak hanya bersifat fisik, tetapi juga mencakup aspek-aspek lain yang bersifat non fisik.

Dan juga senada yang diucapkan oleh Kusumohartono (dalam BKPB, 2009: 11) menyatakan bahwa pelestarian merupakan kegiatan penting dan utama, sebab tanpa pelestarian maka kegiatan pembinaan dan pemanfaatan tidak dapat dilaksanakan. Oleh karena itu, upaya pelestarian penyelamatan data pelestarian sumberdaya arkeologi perlu mendapat perhatian utama untuk dikembangkan dan dimasyarakatkan.

\section{Kondisi Kebendaan Situs Peninggalan Sejarah}

Situs kebendaan peninggalan sejarah di Kabupaten Ponorogo sebelum diperhatikan serius oleh pemerintah, mengalami berbagai kendala yakni kehilangan dan perawatan yang tidak sesuai. Tahun 2002 sampai 2003 adanya kasus kehilangan yang terjadi di Kantor Kabupaten Ponorogo. Pemerintah bersama staf DINKEBPARPORA sudah melaporkan kasus ini sampai ke Mabes Polri dan juga Badan Pengawsan Cagar Budaya Trowulan. Disamping pelaporan lewat jalur resmi sudah dilakukan, jalur non formal juga 
dilaksanakan, tapi nyatanya tidak bisa ketemu.

Untuk penanganan kurun waktu 2 sampai 3 ini pemerintah memberdayakan juru pelihara di setiap situs. Seperti situs Tegal Sari, situs Bathoro Katong, situs Srandil, dan situs Jayengrono sudah. Sedangkan arca yang berada di kantor kabupaten dan kantor pendopo sudah ditarik oleh Balai kita taruh di Balai Penyelamatan Benda Cagar Budaya Jln. Ukel di Kelurahan Kertosari Ponorogo. Untuk kondisinya ada yang di cat dengan warna perak, hal ini dari pemerintah agar kelihatan bagus. Namun cara tersebut justru salah dalam penangananya, karena dapat merusak tekstur batu.

Arca yang ditaruh di BPBCB Ponorogo ada 14 arca, arca-arca untuk diamankan supaya tidak hilang, karena di kantor kabupaten banyak yang hilang. Hilangnya arca ini tidak diketahui oleh petugas, ketika pemerintah Kabupaten Ponorogo membangun gedung lantai 8 atau yang saat ini disebut Gedung Pemkab sekitar tahun 2002-2003. Jumlah yang hilang kurang lebih ada 13 arca.

Penanganan situs Sampung, pemerintah sudah memasang papan tulis dan diplot bahwa Sampung merupakan kawasan situs Medang. Karena sering ditemukan beberapa arca. Sedangkan unutk situs Bantharangin sudah ditetapkan bukan situs, pemerintah menetapkan hanya prasasti. Untuk penemuan arca paling banyak berada di Sampung di situs Medang sebanyak 90\%, karena dulunya Sampung merupakan kerajaan Medang Kamulan. Di Karang Patihan di desa Beji juga terdapat situs pertirtaan, semacam bilik atau kolam untuk mandi. Namun kondisi dari pertirtaan sangat memprihatinkan. Situs tersebut mengalami kerusakan karena adanya isu adanya pengrusakan masyarakat yang mengandung unsur musrik.

Dinas Pariwisata Kebudayaan Pemuda dan Olahraga juga menemukan uang kepingan logam yang bertuliskan tulisan Cina, diketemukan di desa Binade Ngrayun. Sedangkan mangkok diketemukan di Sambit dan Sawo. Sebagian benda peninggalan sejarah ini sebagian mengalami kerusakan.

\section{Respon Masyarakat Mengenai Pelestarian Situs}

Respon masyarakat Ponorogo berkaitan dengan pelestarian peninggalan situs sejarah, pada umunya memiliki kesamaan. Perihal pelestarian situs masyarakat mendukung dengan adanya kebijakan pemerintah, untuk benar-benar memperhatikan mengenai pelestarian situs ini. Adanya respon yang positif dari masyarakat Ponorogo khususnya masyarakat yang berada di kawasan situs.

Kepedulian masyarakat ini tentunya menjadikan pemerintah untuk menjadikan lebih giat untuk melakukan perbaikan sistem kebijakan pelestarian situs di Kabupaten Ponorogo. Tidak hanya pemerintah saja, masyarakat juga harus mendukung program dari pemerintah ini. Karena masyarakat juga termasuk komponen yang penting dalam mengupayakan pelestarian situs. Masyarakat merupakan stake holder, dimana masyarakat merupakan salah satu pemangku kebudayaan. Khususnya peninggalan baik situs maupun benda masyarakat adalah salah satu komponen penting untuk keberlangsungan pelestarian situs benda cagar budaya ini.

Selain itu pemerintah perlu mengadakan adanya sosialisasi terhadap masyarakat Ponorogo secara luas, pentingnya akan hal pelestarian warisan budaya ini. Karena untuk pemerintah sendiri kurang mengadakan sosialisai secara luas. Masyarakat Kabupaten Ponorogo juga banyak yang tidak tahu alasan kenapa situs peninggalan sejarah ini perlu dilestarikan. Mengingat pemerintah terhitung baru dalam keseriusannya untuk menangani pelestarian situs. Maka dari itu adanya respon yang positif ini akan menjadikan pemerintah khususnya Dinas Kebudayaan Pariwisata Pemuda dan Olahraga (DINKEBPARPORA) Ponorogo untuk lebih giat lagi melakukan kebijakan yang tegas terhadap pelestarian benda cagar budaya ini.

\section{E. Manfaat Situs Bagi Pendidikan Kearifan Sejarah Lokal \\ Dalam Undang-Undang Republik} Indonesia No. 11 Tahun 2010 pasal 85 ayat 1 yang berbunyi: pemerintah, pemerintah daerah, dan setiap orang dapat 
memanfaatkan cagar budaya untuk kepentingan agama, sosial, pendidikan, ilmu pengetahuan, teknologi, kebudayaan, dan pariwisata. Mengacu UUD RI No. 11 Pasal 85 ayat 1 Tahun 2010 mengenai pemanfaatan situs cagar budaya, situs merupakan sarana pembelajran yang efektif, karena situs termasuk dalam pembelajaran kurikulum 2013. Pembelajaran pada situs peninggalan sejarah ini termasuk pembelajaran out class, pembelajaran di luar kelas. Situs maupun benda peningggalanya termasuk dalam bahan sumber pelajaran IPS, terutama pelajaran sejarah. Untuk menggali ilmu sejarah, khususnya anak-anak sekolah dan mahasiswa.

Di Ponorogo pemanfaatan situs dalam dunia pendidikan sudah digalangkan oleh pemerintah melalui kegiatan tahunan. Melalui kegiatan tahunan pemilihan Kakang Senduk, pemerintah Kabupaten Ponorogo memberikan pengenalan situs sejarah kepada kontestan yang ikut pada ajang ini. Dengan memberikan pengenalan sejarah lokal Kabupaten Ponorogo, kontestan diminta untuk memahami sejarah dari kota Ponorogo melalui pembelajaran di setiap situsnya. Situs sejarah baik peninggalannya, merupakan sumber belajar yang efisien dalam proses pembelajarannya. Memanfaatkan situs sejarah sebagai sumber belajar merupakan hal penting yang perlu diaplikasikan dalam pendidikan, sebab situs sejarah merupakan salah satu sumber sejarah yang dapat memberikan gambaran suatu peristiwa dengan lebih konkrit dan nyata kepada siswa. Salah satu prinsip dari pelaksanaan kurikulum pendidikan 2013 saat ini juga mendukung untuk pelaksanaan pemanfaatan situs sejarah sebagai sumber belajar.

Kegunaan situs bersejarah baik peninggalannya adalah sebagai salah satu sarana sumber belajar unutk pendidikan kearifan lokal. Pentingnya pemanfaatan situs tersebut karena dapat dikaitkan dengan pendidikan karakter. Berhubungan dengan pemanfaataan bagi generasi pelajar terutama dalam menanamkan pendidikan karakter yang berbudaya, menghargai akan warisan budayannya untuk kemajuan pendidikan khususnya pendidikan sejarah kearifan lokal Kapubaten Ponorogo.

\section{Penutup}

\section{A. Simpulan}

Berdasarkan temuan penelitian, pembahasan yang telah disampaikan dapat disimpulkan bahwa pemerintah Kabupaten Ponorogo dalam kebijakan perlindungan pelestarian situs peninggalan sejarah mengacu pada Undang-Undang Republik Indonesia No. 11 Tahun 2010 tentang cagar budaya. Dinas Kebudayaan Pariwisata Pemuda dan Olahraga adalah badan dinas pemerintah yang menangani kebijakan pelestarian situs di Ponorogo. Dalam mengupayakan kebijakan pelestarian situs menemui berbagai faktor-faktor meliputi, permasalahan anggaran pendanaan perawatan, pengelolaan yang kurang maksimal, penataan ruang yang tidak terstruktur, keterbatasan tenaga ahli, dan juga adanya unsur mistis maupun klenik dari masyarakat sekitar situs. Kinerja pemerintah khususnya Dinas DINKEBPARPORA Ponorogo kurang maksimal, ini dikuatkan dari adanya kasus-kasus pencurian. Untuk pendataan lapangan mengenai data situs maupun benda cagar budaya, pemerintah Kabupaten Ponorogo baru menyusun pembukuan yang sedang dalam proses.

Dalam kurun waktu 3 tahun ini pemerintah benar-benar serius untuk memperhatikan pelestarian situs peninggalan sejarah. Dinas DINKEBPARPORA bersama masyarakat membentuk Balai Penyelamatan Benda Cagar Budaya, hal ini mendapat dukungan dari masyarakat. BPBCB ini terletak di Jln. Ukel No. 20 Desa Kertosari, tepatnya di Kantor Desa Kertosari. Balai penyelamatan ini menggunakan ruangan bekas sekolah dasar Kertosari. Arca-arca yang terdapat di balai penyelamatan ini merupakan penarikan dari penemuan yang tersebar di wilayah Ponorogo, termasuk yang ada di kantor PEMKAB, kondisi dari temuan arca-arca ini terbilang memprihatinkan.

Tujuan kebijakan pelestarian ini untuk menjaga kelestarian warisan budaya. Pemerintah dan juga masyarakat harus 
mampu bekerjasama memberdayakan warisan budaya, terutama pemanfaatan dalam konteks pendidikan. Situs peninggalan sejarah juga dapat digunakan sebagai sumber belajar sejarah, khususnya sejarah lokal. Kabupaten Ponorogo sudah menjalankan program pemanfaatan situs peninggalan sejarah ini untuk sarana edukasi, contohnya untuk kegiatan tahunan yaitu Perekrutan Kakang Senduk.

\section{B. Saran}

Setelah melakukan penelitian ini, ada beberapa saran dari peniliti untuk Pemerintah Kabupaten Ponorogo, Masyarakat Ponorogo, Guru/pendidik di Kabupaten Ponorogo serta Progam Studi Pendidikan Sejarah FPIPS IKIP PGRI MADIUN diantaranya sebagai berikut:

1. Bagi Pemerintah Kabupaten Ponorogo Bagi Pemerintah Kabupaten Ponorogo untuk lebih memperhatikan keseriusan dalam kebijakan pelestarian situs peninggalan sejarah, terutama dalam penanganannya untuk perawatan, pendataan dan perhatian khusus terhadap benda cagar budaya dan juga dapat bekerjasama dengan masyarakat agar mampu terlaksana dengan maksimal.

2. Bagi Masyarakat Ponorogo

Masyarakat dapat ikut berperan dalam melestarikan peninggalan warisan budaya dengan berkerjasama dengan pemerintah kota, untuk ikut menjaga keberlangsungan pelestarian dan mampu memanfaatankan keberadaan situs peninggalan agar berdampak positif bagi masyarakat.

3. Bagi Guru/Pendidik di Kabupaten Ponorogo

Selain sebagai mentor pendidikan guru dalam proses pembelajaran harus mampu untuk lebih kreatif dalam penggunaan media pembelajaran, peniliti juga berharap penggunaan media situs cagar budaya untuk lebih sering dimanfaatkan dan dipergunakan oleh Guru dalam pembelajaran, tidak hanya mengacu pada pembelajaran di dalam kelas.

4. Bagi Progam Studi Pendidikan Sejarah FPIPS IKIP PGRI MADIUN

Kebijakan pemerintah dalam pelestarian situs peninggalan sejarah juga dapat berfungsi sebagai sumber belajar sejarah lokal, maka adanya manfaat wawasan untuk kebijakan pelestarian ini dapat dijadikan referensi ilmu karena mengacu pada konteks Program Studi Sejarah

\section{Daftar Pustaka}

Ali, F. dan Alam, A. S. 2012. Studi Kebijakan Pemerintah. Bandung: PT. Refika Aditama.

Hendro, E. P. 2008. Konservasi Bangunan Kontruksi Kayu Di Lingkungan Kawasan Masjid Agung Demak. Jurnal Konservasi Benda Cagar Budaya. Borobudur Vol. II No. 2. Magelang: Balai Konservasi Peninggalan Borobudur.

Islamy , M. I. 2009. Prinsip-Prinsip Perumusan Kebijaksanaan Negara. Jakarta: Bumi Aksara.

Kusumohartono. 1993. Berkala Arkeologi Teтu Evalusi Penelitian Wonoboyo. Klaten Jawa Tengah: Balai Arkeologi Yogyakarta.

Mahmud, M. I. dan Mas'ud, Z. 2012. Warisan Sumber Daya Arkeologi Dan Pembangunan. Yogyakarta: Ombak Dua.

Miles, M. B. dan Huberman, A. M. 1992. Analisis Data Kualitatif. Jakarta: Universitas Indonesia.

Moleong, L. J. 2012. Metodologi Penelitian Kualitatif. Bandung: PT. Remaja Rosdakarya.

Nazir, M. 2009. Metode Penelitian. Jakarta Selatan: Ghalia Indonesia.

Prasetyo,Y. dan Hartono, Y. 2014. Sejarah Tari Keling dan Upaya Pelestarianya (Studi Historis Sosiologis di Dusun Mojo Desa Singgahan Kecamatan Pulung Kabupaten Ponorogo Tahun 1942-2012). Agastya Jurnal Sejarah dan Pembelajaran Vol. 04, No. 01. Madiun: Prodi Pendidikan Sejarah.

Purwowijoyo. 1985. Babad Ponorogo Jilid IVII. Ponorogo: Dinas Pariwisata Dan Seni Budaya Pemerintah Kabupaten Ponorogo Propinsi Jawa Timur.

Soebijantoro. 2013. Undang-Undang Benda Cagar Budaya Di Era Otonomi Daerah (Suatu Harapan Dan Tantangan). Agastya Jurnal Sejarah dan 
Pembelajaranya Vol. 03. No. 01.

Madiun: Prodi Pendidikan Sejarah.

Sugiyono. 2001. Metodologi Penelitian Bisnis.

Bandung: Alfabeta.

. 2008. Metodologi Penelitian

Kuantitatif Kualitatif dan $R \& D$.

Bandung: Alfabeta.

2012. Metodologi Penilitian

Penidikan. Bandung: Alfabeta.

. 2013. Metode Penelitian Manajemen cetakan ke 1. Bandung: Alfabeta.

2013. Metodologi Penelitian Kualitatif dan R\&D cetakan ke 13. Bandung: Alfabeta.

Sugono, D. 2008. Kamus Besar Bahasa Indonesia Pusat Bahasa. Jakarta: PT Gramedia Pustaka Utama.

Suharno. 2013. Dasar-Dasar Kebijakan Publik Kajian Proses dan Analisis Kebijakan. Yogyakarta: Ombak.

Suhartono, Y. 2009. Pelestarian Sumber Daya Arkeologi Dalam Konteks Keruangan di Kawasan Borobudur (Studi Kasus Candi Borobudur, Mendut dan Pawon). Jurnal Konservasi Benda Cagar Budaya Borobudur Vol. II No. 03. Magelang: Balai Konservasi Peninggalan Borobudur.

Sukmadinata, N. S. 2010. Metode Penelitian Pendidikan. Bandung: PT. Remaja Rosdakarya.

Sutopo H. B. 2002. Metodologi Penelitian Kualitatif. Surakarta: Sebelas Maret University Perss.

Sutrasno. 1975. Sejarah dan Ilmu Pengetahuan (History and Sains). Jakarta: Pradnya Paramita.

Umar Husein. 2011. Metode Penelitian Untuk Skripsi dan Tesis Bisnis edisi kedua. Jakarta Utara: PT. Rajagrafindo Persada.

Undang-Undang Republik Indonesia Nomor 11 tahun 2010 Tentang Cagar Budaya. Jakarta: Menteri Hukum dan Hak Asasi Manusia Republik Indonesia. 